\title{
Determinants of higher education choices and student satisfaction: the case of Poland
}

\author{
Bogdan Sojkin • Paweł Bartkowiak • Agnieszka Skuza
}

Published online: 24 June 2011

(C) The Author(s) 2011. This article is published with open access at Springerlink.com

\begin{abstract}
The dynamic changes in tertiary education that were observed in Poland for the last 20 years transformed the Polish educational market and led to the immense expansion of educational institutions. The rapid increase in the number of students that continued until 2006 is however over and Polish universities have begun to compete for their clients. Increased competition along with the pessimistic forecasts for Poland with regard to demographic changes result in the growing demand for the knowledge on determinants of student educational choices and satisfaction. Although the amount of studies in this field is growing, Poland is still substantially underrepresented in the current research. The purpose of this article was to examine the underlying factors behind the choices that Polish students make while pursuing their tertiary education. The research method that combines focus groups' discussions and a survey study among 1,420 business major students helped us to identify the factors behind three phases of the decision making process: pursuing higher education; information search along with final choice of a university; and satisfaction from chosen studies. Our research implies that decision making with regard to tertiary education is multifaceted and longitudinal as it combines a different set of factors in each stage of the decision making process.
\end{abstract}

Keywords Higher education - Determinants of university choice · Student satisfaction · Educational choice

\footnotetext{
B. Sojkin · A. Skuza $(\bowtie)$

Department of Product Marketing, Poznań University of Economics, Al. Niepodległości 10, 61-875 Poznań, Poland

e-mail: agnieszka.skuza@ue.poznan.pl

B. Sojkin

e-mail: bogdan.sojkin@ue.poznan.pl

P. Bartkowiak

Department of Strategic Management, Poznań University of Economics, Al. Niepodległości 10, 61-875

Poznań, Poland

e-mail: pawel.bartkowiak@ue.poznan.pl
} 


\section{Introduction}

For the last 20 years Poland has gone through a rapid process of transformation of political, economical, and social systems, which immensely increased the demand for higher education and influenced the changes in the education system. Until the 1980s, higher education in Poland was based on quite the "elitist labour market-led polytechnic system" (Koivula and Rinne 2006). Tertiary education institutions were centralized and controlled by the state, and non-public schools did not exist. Yet, the fall of communism in 1989 brought a tremendous massification of higher education which was achieved not just through non-public expenditures, but also through private institutions (Usher 2009).

Between 1990 and 2005 the number of higher education institutions increased almost four times from 112 (in 1990) to 427 (in 2005) and the number of students grew by almost $500 \%$ from 404.000 in 1990 to over 1.950 .000 in 2005 (Rozanski 2008; CSOP 2010b). The increase in the number of schools was the result of the new law introduced in 1990 which allowed non-public universities to be founded (in 2005 out of 427 higher education institutions 301 were non-public).

The dynamic growth of interest in tertiary education, which was attributed mainly to an increasing demand of a highly competitive job market, helped to increase the tertiary education gross enrollment ratio $\left(\mathrm{GER}^{1}\right.$ ) from $12.9 \%$ in 1990 to over $50 \%$ in 2009, which allowed Poland to achieve one of the highest GER in OECD countries (OECD 2009). It also helped to raise the number of population with higher education (aged 15 and more) from around 7\% in 1990 to $17 \%$ in 2008 (CSOP 2010b).

The growing number of students that continued to increase until 2005 led to the rapid expansion of universities, construction of new institutions, and the mass hiring of new teaching staff (Kwiek 2003; Usher 2009). However in 2006 for the first time in the postcommunist Polish history, a steady decline in the number of students begun. Overall the number of students decreased to 1.900 .000 in 2009 (see Fig. 1) and is expected to decrease further (CSOP 2010a). The demographic forecasts for Poland state that in 2010 the number of population aged between 19 and 24 decreased to 3.4 million (comparing to 3.9 million in 2002), which will further decrease to 2.8 million in 2015 and 2.3 million in 2020 (CSOP 2009). According to a United Nations Report, the demographic trends with a declining birth rate place Poland among European countries with the highest decreases in population (UN Report 2005).

The declining number of students along with the biggest number of higher education institutions in Europe (Kula 2008) changed the intensity of competition among universities in Poland and attracted much more attention to marketing efforts, which was so far highly neglected (particularly by public institutions). The notion of treating higher education as a marketable commodity, where students should be treated as customers (Lloyd 2005; Cremonini et al. 2008; Taylor et al. 2008) has become valued.

Following the customer-oriented approach, different research has tried to evidence which factors are primarily considered by students while making their educational choices (García et al. 2007; Menon et al. 2007; Pimpa 2005; Sullivan 2006; Menon 2004; Osborne et al. 2004; Jimenez and Salas-Velasco 2000). While the amount of research is growing (García et al. 2007), very little is known on how secondary school graduates decide to continue their education at the college level, what are the factors behind the university selection, and which variables influence satisfaction from those choices.

\footnotetext{
${ }^{1}$ GER is a statistical measure used to report a country's level of education.
} 


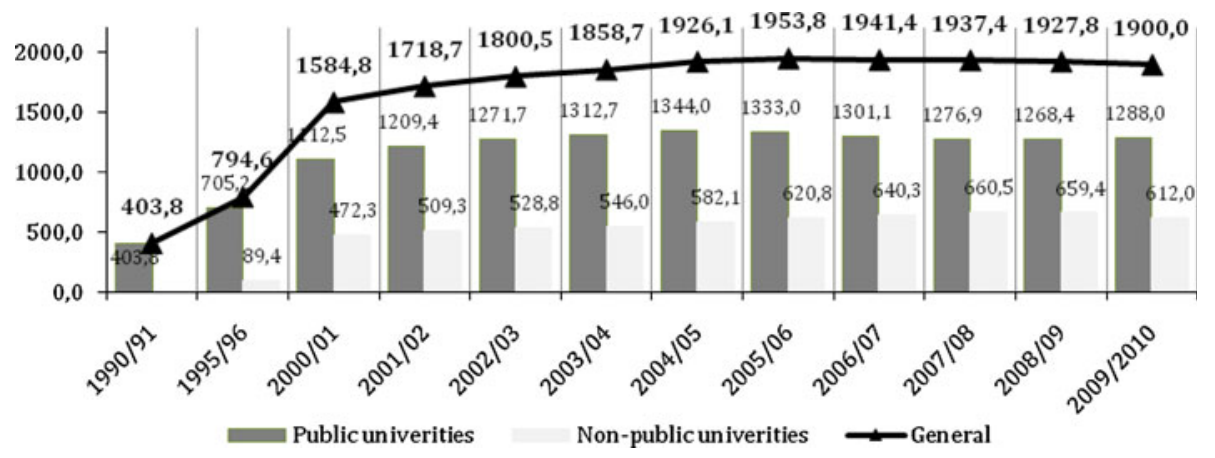

Fig. 1 Number of students in Poland in 1990-2009 (in thousands). Source Central Statistical Office of Poland, Statistical Yearbook of the Republic of Poland, Warsaw: Statistical Publishing Establishment; various years

There is a particular dearth of studies on educational choices in the emerging markets of the Central and Eastern Europe and Poland is substantially underrepresented in current research. However, as explained earlier the explosion of the educational sector in Poland and forthcoming trends of a demographic downturn, make higher education institutions pay increasing attention to the effectiveness of their marketing activities, which primarily needs better understanding of factors impacting students educational choices and sources of their satisfaction.

Building on existing literature about college choice models and factors influencing students' choice of undergraduate or graduate programs (Cremonini et al. 2008; Cabrera et al. 2008; Chen 2007; Menon et al. 2007; Menon 2004; Kohn et al. 1976; Chapman 1986; Jackson 1982; Hossler and Gallagher 1987; Hanson and Litten 1982; Somers et al. 1999), this paper presents findings on the choice of the university education in Poland with the particular focus on business education. First, we investigate the factors that are likely to be associated with pursuing university education, which following the work of Hossler and Gallagher (1987), we included in the stage called "a predisposition stage". Second, we attempt to specify the characteristics of the exploration stage which combines information search and factors behind university choice. Following the rational choice decision-making process (Mintzberg et al. 1976; Wedley and Field 1984) we also added the stage of evaluation of decision outcomes, which is rarely investigated as a part of the educational decision making process. We believe however that analysis of the complete decision making process can provide higher institutions with a more complete understanding of their clientele.

This paper is organized as follows: First the methodology of this study is presented and includes a combination of qualitative and quantitative research methods. Research findings are then summarized, which are further discussed within the Polish context. This is followed by implications and research limitations.

\section{Method}

This study has an exploratory character. It is a combination of qualitative and quantitative research methods, which were organized around three themes: (a) how decisions about 
pursuing university studies are made (decisions prior to studying); (b) how decisions about the choice of a university are made and what are the sources of information; and (c) which factors influence satisfaction from studying in a chosen university.

Qualitative research comprised fifteen focus groups with each group including ten participants. They were recruited from the public and non-public universities located in the Wielkopolska region. The major goal of qualitative study was to gather a broad range of opinions about how Polish students make their university choices. Focus groups helped us to avoid the possible misinterpretations that could emerge in a pre-specified research design which is used in developed countries, but may not fit the reality of emerging economies (Soja 2008).

In the quantitative research, a survey method was used. The survey items were developed based on focus group discussions and a review of previous research findings about students educational choices, which propose a wide variety of economic models (based on the idea of rational cost-benefit analysis), sociological models (related to aspirations, family conditions, school environment, etc.) or combined models (Hossler et al. 1999; Jackson 1982; Kohn et al. 1976; Chapman 1986; Hanson and Litten 1982; Hossler and Gallagher 1987; Cremonini et al. 2008; Chen 2007).

The main part of the questionnaire included 84 statements measured with a multiple five-point Likert-type scales (ranging from 1-strongly disagree to 5-strongly agree). Out of 84 statements, 23 measured variables behind decisions about pursuing higher education, 27 measured the significance of variables determining decisions about choice of a university, and 34 measured the satisfaction factors from studying in a chosen university. Students were also asked about the main sources of information they used while making their university choice (internet, rankings, university brochures, friends' recommendations, etc.).

Further, respondents were asked about their personal data such as gender, age, type of targeted university (public or non-public), family average income level, and place of living prior to studies (village or a city).

Sample

The data was collected in 2008. The questionnaire was distributed to students of business majors in 16 public and 24 private universities in the Wielkopolska region. Quota sampling was used to choose the sample. Researchers divided population into subgroups based on the following criteria: gender, age, and type of university (public or non-public). Then the proportions of these subgroups in the entire population were identified. These proportions were used while the final sampling was conducted. Although this method does not give a totally representative sample (as only the selected traits of the population were taken into account in forming the subgroups) it helps to ensure that chosen subgroups are properly represented in the study.

Out of a total of 2,350 surveys sent, 1,420 usable questionnaires were received, which gives a response rate of $60.4 \%$. Among 1,420 respondents, $62 \%$ were women, $18 \%$ were less than 19 years old, $65 \%$ were in the age of $20-29$, and $17 \%$ were older than 30 . Fiftyfour percentage of respondents studied in non-public universities and $46 \%$ came from public universities. Fifty percentage of the respondents came from families with a country average level of income. Respondents with a family income level below the country average constituted 19 , and $27 \%$ of the respondents had a family income over the country 
average. $66 \%$ of the participants were living in a city while $34 \%$ of them came from villages.

\section{Statistical analysis}

The questionnaire applied in this study was first tested on two groups of 50 students. The Pearson's correlation coefficient was calculated to compare the scores and the reliability correlation of scales of two groups of students was computed with the purpose to evaluate the stability of the scale. After unidimensionality of the scale and reliability (0.92) were confirmed, the consistency of the inter-item reliability of the questionnaire was calculated. All factors achieved the required reliability level, with Cronbach's alphas exceeding the criterion of 0.7 (Nunnally 1978).

After the instrument was tested, the researchers conducted the main research. The exploratory factor analysis (EFA) was then performed to test the scale's construct validity. All items of the survey loaded in the similar factors. The Kaiser-Meyer-Olkin (KMO) measure of sampling adequacy and Bartlett's Test of Sphericity (BTS), which were applied to the data prior to a factor extraction, indicated that the data set of all three groups of determinants was suitable for factor analysis. The extracted factors (with eigenvalues

Table 1 Exploratory factor analysis results

a Cumul. variance extracted 51.1\%; KMO_.846; Bartlett's test of sphericity:

$\chi^{2}=7,827.903 ; \mathrm{df}=253$;

$p \leq 0.001$

b Cumul. variance extracted $56.8 \%$; KMO-.887; Bartlett's test of sphericity:

$\chi^{2}=16,356.439 ;$ df $=561 ;$

$p \leq 0.001$

c Cumul. variance extracted $61.3 \%$; KMO_.914; Bartlett's test of sphericity:

$\chi^{2}=14,139.855 ;$ df $=351$;

$p \leq 0.001$

${ }^{\mathrm{d}}$ Original variables which loaded on the factors are presented in "Appendix"

\begin{tabular}{ll}
\hline $\begin{array}{l}\text { No. of } \\
\text { items }\end{array}$ & Loadings \\
& $\begin{array}{l}\text { Cronbach's } \\
\alpha\end{array}$ \\
\hline
\end{tabular}

Choice of pursuing higher education ${ }^{\mathrm{a}}$

Professional advancement 4

Family opinion and expectation

Family financial support 2

Better chances to find a job 3

Choice of a university ${ }^{\mathrm{b}}$

Marketing efforts

Professional advancement $.64-.78 \quad .800$

University tradition

Courses offered

University reputation

Family opinion and expectations

Cost of studies and accessibility 3 of financial aid

Satisfaction from studying ${ }^{c}$

Professional advancement

$.67-.73 \quad .720$

Pragmatism of knowledge

$.63-.72 \quad .740$

Courses offered

$.66-.74 \quad .722$

Educational facilities

$.66-.70 \quad .804$

Social conditions

$.64-.81 \quad .738$

Faculty's educational and

67-.73 .718 
greater than 1) with their reliability measures are presented in Table 1. Items with loadings on each factor below 0.60 were consequently removed.

To analyze the impact of control variables (gender, age, type of the university, type of graduated high school, family average income level, and the place of living prior to studies) on educational choice factors the $t$ test and one-way ANOVA with post-hoc test were computed. While the differences with regard to the first three control variables were evidenced, the outcomes of this research revealed no significant differences while statistics was run for: type of graduated high school, place of living prior to studies, and family average income level.

\section{Results}

Factors underlying decisions about pursuing university education

This study identified five main factors determining a decision to pursue a university education (Table 2). The most influential factors were: family opinion and expectations $(\mathrm{M}=3.69)$, and student-like type of life $(\mathrm{M}=3.62)$. Much lower means were reported regarding family financial support $(M=2.61)$, better chances to find a job $(M=1.84)$, and professional advancement $(\mathrm{M}=1.83)$. The last two factors were much lower from what was expected.

The results of this study showed interesting findings when we controlled for gender and age. As shown in Table 2 female students reported statistically significant differences when compared to their male counterparts with regard to four out of five factors.

The results of our research also uncovered differences among students representing different age groups (Table 3). One-way ANOVA with post-hoc test was used to identify the influence of age on the university education choices. The biggest differences in mean scores were found with regard to student-type of life $(\mathrm{F}(1,401=30.07 ; p \leq 0.001)$ and better chances to find a job $(\mathrm{F}(1401=11.07 ; p \leq 0.001)$.

Factors influencing decisions about the choice of a university: choice stage

In this stage of the decision making process, we diagnosed both the information sources that students most often use while searching for information about universities, and the determinants that actually influenced their final choice.

Table 2 Factors determining decisions about pursuing university education-general and controlled for gender

\begin{tabular}{llllll}
\hline Choice & $\begin{array}{l}\text { General } \\
\mathrm{N}=1,420\end{array}$ & $\begin{array}{l}\text { Female } \mathrm{M}(\sigma) \\
\mathrm{N}=885\end{array}$ & $\begin{array}{l}\text { Male } \mathrm{M}(\sigma) \\
\mathrm{N}=535\end{array}$ & t-statistic & $p$-value \\
\hline Family opinion and expectations & $3.69(.86)$ & $3.73(.86)$ & $3.62(.84)$ & $2.34^{*}$ & .020 \\
Student-type of life & $3.62(.87)$ & $3.76(.84)$ & $3.36(.88)$ & $8.39^{* * *}$ & .000 \\
Family financial support & $2.61(.84)$ & $2.60(.85)$ & $2.62(.84)$ & -.36 & .719 \\
Better chances to find a job & $1.84(.72)$ & $1.81(.72)$ & $1.89(.74)$ & $-2.10^{*}$ & .036 \\
Professional advancement & $1.83(.51)$ & $1.78(.48)$ & $1.91(.54)$ & $-4.77^{* * *}$ & .000 \\
\hline
\end{tabular}

$* p \leq 0.05 ; * * p \leq 0.01 ; * * * p \leq 0.001$ 
Table 3 Age influence on pursuing university education decisions

\begin{tabular}{llllll}
\hline Choice & $\begin{array}{l}\text { Less than } \\
19 \text { years old } \\
\mathrm{N}=254 \\
\mathrm{Y}=\text { younger }\end{array}$ & $\begin{array}{l}\text { 20-29 years old } \\
\mathrm{N}=928\end{array}$ & $\begin{array}{l}\text { More than } \\
\text { 30 years old } \\
\end{array}$ & $\begin{array}{l}\text { ANOVA } \\
\text { F-values }\end{array}$ & Differences \\
\hline $\begin{array}{l}\text { Family opinion and } \\
\text { expectations }\end{array}$ & $3.63^{1}(.84)$ & $3.67^{1}(.85)$ & $3.83^{2}(.93)$ & $3.70^{* *}$ & $\mathrm{Y}, \mathrm{M}<\mathrm{O}$ \\
$\begin{array}{l}\text { Student-type of life } \\
\begin{array}{l}\text { Family financial } \\
\text { support }\end{array}\end{array}$ & $\begin{array}{l}3.33^{1}(.84) \\
2.59^{1}(.80)\end{array}$ & $\begin{array}{l}3.62^{2}(.85) \\
2.61^{1}(.85)\end{array}$ & $\begin{array}{l}3.94^{3}(.93) \\
2.61^{1}(.86)\end{array}$ & $\begin{array}{c}30.07^{* * *} \\
.067\end{array}$ & $\mathrm{Y}<\mathrm{M}<\mathrm{O}$ \\
$\begin{array}{l}\text { Better chances to find a } \\
\text { job }\end{array}$ & $1.74^{1}(.66)$ & $1.82^{1}(.68)$ & $2.04^{2}(.91)$ & $11.07^{* * *}$ & $\mathrm{Y}, \mathrm{M}<\mathrm{O}$ \\
$\begin{array}{l}\text { Professional } \\
\text { advancement }\end{array}$ & $1.89^{1}(.53)$ & $1.81^{1}(.48)$ & $1.87^{1}(.60)$ & 3.50 & $\mathrm{Y}, \mathrm{M}, \mathrm{O}$ \\
\hline
\end{tabular}

The mean values are accompanied by superscripts 1,2 and 3 . They signify that value 1 is statistically higher from 2 , and 2 is significantly higher than 3 , at $\alpha=0.05$ level of significance. Significance tested with Student-Newman_Keuls test for post hoc multiple comparisons: * $p \leq 0.05 ; * * p \leq 0.01$; *** $p \leq 0.001$

The most often used information source was the internet (university www, forums, opinions) mentioned by over $63 \%$ of the students, followed by university brochures and handbooks (54\%), friends' recommendations (34\%), educational fairs (30\%), campus visits $(20 \%)$, and rankings $(19 \%)$.

With regard to the factors determining the final choice of a university, the most influential was professional advancement with the mean score of $\mathrm{M}=3.01$ (Table 4). Courses offered and cost of studies \& accessibility of financial aid were least important with the mean score below 2.0.

While we controlled for gender, the $t$ test revealed statistically significant differences for three factors. As shown in Table 4 male students perceived university reputation, courses offered, and cost of studies \& accessibility of financial aid as more important than their female counterparts.

Table 4 Factors determining decisions about the choice of a university — general and controlled for gender

\begin{tabular}{llllll}
\hline Choice & $\begin{array}{l}\text { General } \\
\mathrm{N}=1,420\end{array}$ & $\begin{array}{l}\text { Female } \mathrm{M}(\sigma) \\
\mathrm{N}=885\end{array}$ & $\begin{array}{l}\text { Male } \mathrm{M}(\sigma) \\
\mathrm{N}=535\end{array}$ & t-statistic & $p$-value \\
\hline Professional advancement & $3.01(1.00)$ & $2.99(1.01)$ & $3.02(1.00)$ & -.47 & .638 \\
University tradition & $2.96(.81)$ & $2.93(.83)$ & $3.00(.80)$ & -1.51 & .132 \\
Marketing efforts & $2.80(.77)$ & $2.83(.80)$ & $2.76(.72)$ & 1.49 & .136 \\
Family opinion and expectations & $2.61(.84)$ & $2.58(.84)$ & $2.65(.84)$ & -1.51 & .130 \\
University reputation & $2.09(.67)$ & $2.04(.64)$ & $2.17(.71)$ & $-3.49 * * *$ & .001 \\
Courses offered & $1.98(.55)$ & $1.93(.52)$ & $2.06(.60)$ & $-4.20^{* * *}$ & .000 \\
Cost of studies \& & $1.98(.93)$ & $1.92(.90)$ & $2.08(.94)$ & $-3.23 * * *$ & .001 \\
$\quad$ & & & & & \\
\hline
\end{tabular}

$* p \leq 0.05 ; * * p \leq 0.01 ; * * * p \leq 0.001$ 
Table 5 Factors determining decisions about the choice of a university controlled for the type of a university

\begin{tabular}{lllll}
\hline Choice & $\begin{array}{l}\text { Public } \mathrm{M}(\sigma) \\
\mathrm{N}=760\end{array}$ & $\begin{array}{l}\text { Non-public } \mathrm{M}(\sigma) \\
\mathrm{N}=635\end{array}$ & t-statistic & $p$-value \\
\hline Professional advancement & $2.89(.97)$ & $3.15(1.03)$ & $-4.58^{* * *}$ & .000 \\
University tradition & $2.95(.83)$ & $2.97(.80)$ & -.60 & .546 \\
Marketing efforts & $2.86(.77)$ & $2.73(.77)$ & $3.17 * *$ & .002 \\
Family opinion and expectations & $2.59(.81)$ & $2.64(.69)$ & -1.27 & .205 \\
University reputation & $1.98(.62)$ & $2.23(.69)$ & $-7.03 * * *$ & .000 \\
Courses offered & $1.95(.55)$ & $2.00(.54)$ & -1.60 & .110 \\
Cost of studies \& accessibility of financial aid & $2.04(.97)$ & $1.92(.86)$ & $2.31^{*}$ & .021 \\
\hline
\end{tabular}

$* p \leq 0.05 ; * * p \leq 0.01 ; * * * p \leq 0.001$

When we controlled for age only one discrepancy was found. ANOVA analysis demonstrated that students differed with regard to professional advancement, and this importance increased with the age progress $(\mathrm{F}(1420)=25.46, p \leq 0.001)$. Post hoc comparisons indicated the following mean scores with respect to the age groups: $\mathrm{M}=2.69$ (19 years old and below), $\mathrm{M}=3.01$ (20-29 years old) and $\mathrm{M}=3.34$ (30 year old and above).

Further differences were found when we controlled for the type of the targeted university (Table 5). Independent sample $t$ test that was performed indicated statistically significant differences with regard to four factors.

Professional advancement and university reputation were more important for those students who targeted non-public universities, while marketing efforts and cost of studies $\&$ accessibility of financial aid were more important for those who decided to submit their applications to a public university.

Factors contributing to the satisfaction from studying in a chosen university

The last group of factors was related to satisfaction predictors from studying in a chosen university. As presented in Table 6, the most important factor of satisfaction was social conditions, followed by professional advancement.

Table 6 Satisfaction factors-general and controlled for gender

\begin{tabular}{llllll}
\hline Factors & $\begin{array}{l}\text { General } \\
\mathrm{N}=1,420\end{array}$ & $\begin{array}{l}\text { Female } \mathrm{M}(\sigma) \\
\mathrm{N}=885\end{array}$ & $\begin{array}{l}\text { Male } \mathrm{M}(\sigma) \\
\mathrm{N}=535\end{array}$ & t-statistic & $p$-value \\
\hline Social conditions & $2.97(.89)$ & $3.04(.91)$ & $2.86(.85)$ & $3.56^{* * *}$ & .000 \\
Professional advancement & $2.86(.90)$ & $2.85(.92)$ & $2.87(.85)$ & -.399 & .690 \\
Pragmatism of knowledge & $2.33(.67)$ & $2.33(.68)$ & $2.34(.65)$ & -.12 & .904 \\
Educational facilities & $2.32(.80)$ & $2.31(.84)$ & $2.32(.74)$ & -.20 & .842 \\
Courses offered & $2.02(.68)$ & $1.97(.68)$ & $2.09(.67)$ & $-3.33^{* * *}$ & .001 \\
Faculty's E\&R achievements & $1.96(.58)$ & $1.93(.57)$ & $2.01(.59)$ & $-2.76^{* *}$ & .006 \\
\hline
\end{tabular}

$* p \leq 0.05 ; * * p \leq 0.01 ; * * * p \leq 0.001$ 
Table 7 Satisfaction factors among the students of different age

\begin{tabular}{llllll}
\hline $\begin{array}{l}\text { Satisfaction } \\
\text { factor }\end{array}$ & $\begin{array}{l}\text { Less than } \\
19 \text { years old } \\
\mathrm{N}=254\end{array}$ & $\begin{array}{l}20-29 \text { years old } \\
\mathrm{Y}=928 \mathrm{M}=\text { middle }\end{array}$ & $\begin{array}{l}\text { More than } \\
30 \text { years old } \\
\mathrm{N}=219 \\
\mathrm{O}=\text { older }\end{array}$ & $\begin{array}{l}\text { ANOVA } \\
\text { F-values }\end{array}$ & Differences \\
\hline $\begin{array}{c}\text { Social } \\
\text { conditions }\end{array}$ & $2.81^{1}(.80)$ & $2.99^{2}(.90)$ & $3.08^{2}(.93)$ & $5.780^{* * * *}$ & $\mathrm{Y}<\mathrm{M}, \mathrm{O}$ \\
$\begin{array}{c}\text { Professional } \\
\text { advancement }\end{array}$ & $2.59^{1}(.74)$ & $2.86^{2}(.89)$ & $3.15^{3}(1.00)$ & $23.280^{* * * *}$ & $\mathrm{Y}<\mathrm{M}<\mathrm{O}$ \\
$\begin{array}{c}\text { Pragmatism of } \\
\text { knowledge }\end{array}$ & $2.17^{1}(.54)$ & $2.37^{2}(.68)$ & $2.38^{2}(.70)$ & $9.240^{* * * *}$ & $\mathrm{Y}<\mathrm{M}, \mathrm{O}$ \\
$\begin{array}{c}\text { Educational } \\
\text { facilities }\end{array}$ & $2.13^{1}(.66)$ & $2.33^{2}(.82)$ & $2.45^{2}(.85)$ & $10.177^{* * * *}$ & $\mathrm{Y}<\mathrm{M}, \mathrm{O}$ \\
$\begin{array}{c}\text { Courses } \\
\text { offered }\end{array}$ & $1.92^{1}(.67)$ & $2.04^{1}(.66)$ & $2.02^{1}(.71)$ & 2.985 & $\mathrm{Y}, \mathrm{M}, \mathrm{O}$ \\
$\begin{array}{c}\text { Faculty's E\&R } \\
\text { achievements }\end{array}$ & $2.02^{1}(.57)$ & $1.96^{1}(.56)$ & $1.91^{1}(.63)$ & 2.047 & $\mathrm{Y}, \mathrm{M}, \mathrm{O}$ \\
\hline
\end{tabular}

The mean values are accompanied by superscripts 1,2 and 3 . They signify that value 1 is statistically higher from 2 , and 2 is significantly higher than 3 , at $\alpha=0.05$ level of significance. Significance tested with Student-Newman_Keuls test for post hoc multiple comparisons: * $p \leq 0.05 ; * * p \leq 0.01$; *** $p \leq 0.001$

Table 8 Satisfaction factors among student from public and non-public universities

\begin{tabular}{lllll}
\hline Satisfaction factor & $\begin{array}{l}\text { Public } \mathrm{M}(\sigma) \\
\mathrm{N}=760\end{array}$ & $\begin{array}{l}\text { Non-public } \mathrm{M}(\sigma) \\
\mathrm{N}=635\end{array}$ & t-statistic & $p$-value \\
\hline Social conditions & $2.89(.88)$ & $3.07(.89)$ & $3.859^{* * *}$ & .000 \\
Professional advancement & $2.79(.88)$ & $2.96(.90)$ & $-3.558^{* * *}$ & .000 \\
Pragmatism of knowledge & $2.29(.64)$ & $2.40(.70)$ & $-2.948^{* *}$ & .003 \\
Educational facilities & $2.23(.76)$ & $2.42(.84)$ & $-4.215^{* * *}$ & .000 \\
Courses offered & $1.97(.67)$ & $2.06(.67)$ & $-2.497^{*}$ & .013 \\
Faculty's E\&R achievements & $1.89(.57)$ & $2.05(.58)$ & $-4.964^{* * *}$ & .000 \\
\hline
\end{tabular}

$* p \leq 0.05 ; * * p \leq 0.01 ; * * * p \leq 0.001$

Some differences were evidenced when we controlled for gender. Women presented higher mean score with regard to social conditions $(\mathrm{t}(1,420)=3.56, p \leq 0.001)$. Male students on the other hand were more satisfied if a chosen university delivered good quality and a variety of courses or when professors' educational and research achievements were high.

There were also statistically significant discrepancies with relation to four out of six factors among different age groups (Table 7). The post hoc comparisons indicated that the mean scores for older students were higher than those of their younger colleagues.

Table 8 presents comparisons of the influence of the type of a university on the importance of satisfaction factors. This study revealed that t-statistics were significant for all six satisfaction factors with the higher means achieved among the students of nonpublic universities. 


\section{Discussion}

This study highlights the basis for educational choices among students of business majors. It adds a new stage to the existing models. Previous research often limits their models to the predisposition and choice stages. Following the literature about rational decision making processes (Mintzberg et al. 1976; Wedley and Field 1984) we decided to add the stage of evaluation of decision outcomes, which allows for identification of the determinants of students' satisfaction. Although it is not the subject of this article and the results of such analysis are not presented in this paper, our study further showed that choice factors can be predictors of 41 percent of variability in satisfaction factors. It means that the knowledge about university choice factors may be valuable in predicting which factors students will consider important while evaluating their satisfaction. For example, those students who chose university tradition, reputation and courses offered as their choice factors, much more often chose faculty's educational and research achievements and pragmatism of knowledge as the basis of their satisfaction. Those who chose professional advancement not only evaluated their satisfaction based on this factor, but also on pragmatism of knowledge, while paying much less attention to social conditions. The last factor was chosen mainly by students considering marketing efforts as their most important choice factor. Although such results require further investigation and much more complex studies, they can shed a light on the importance of the possible links between university choice factors and students' satisfaction determinants.

The knowledge about satisfaction factors is particularly important as various research reports that around 20-30\% of students do not come back to their initial institution for the second year (Gazeta Prawna 2011; Rausch and Hamilton 2006). Other research also claims that satisfaction from the university affects students performance (Bean and Bradley 1986; Pike 1991), is a predictor of student persistence at a university (Aitken 1982; Tinto 1993), or helps a university to be more competitive and attract more students (Lee et al. 2000).

Based on our findings we propose an integrative framework which can be helpful in understanding students' preferences in three different stages of a decision making process. When we ran statistics for control variables, various differences emerge but the order of importance of factors remained almost unchanged. This signifies that control variables do not change the basic assumptions of our concept. Figure 2 illustrates the proposed choice process in Poland.

Below we discuss university choice process in a broader Polish context, which will help to understand the reasons behind attitudes and behaviors of Polish students.

While comparing the stages of our framework, several research findings call for special attention. As better chances to find a job was one of the least important factors in a predisposition stage and non-existent in the choice and evaluation stages, it can be assumed that Polish students believe that a university degree does not have a potential to increase their future work opportunities, which we found contradictory to other research findings (see Brinkworth et al. 2009; Jimenez and Salas-Velasco 2000; Rochat and Demeulemeester 2001; Montmarquette et al. 2002). Such attitudes can come from the high unemployment rate among university graduates that is reported in Poland (Polish Ministry of Education Report 2005). The similar results can be found in a study of Aldemir and Gulcan (2004), who evidenced that economic difficulties can influence students' perception of low significance of a university degree for increasing their chances to find a job.

Second, professional advancement, although regarded as one of the least important factors in the first stage of the decision making process, was the most important factor in the second and third stage. Such results can give an important notion that universities 


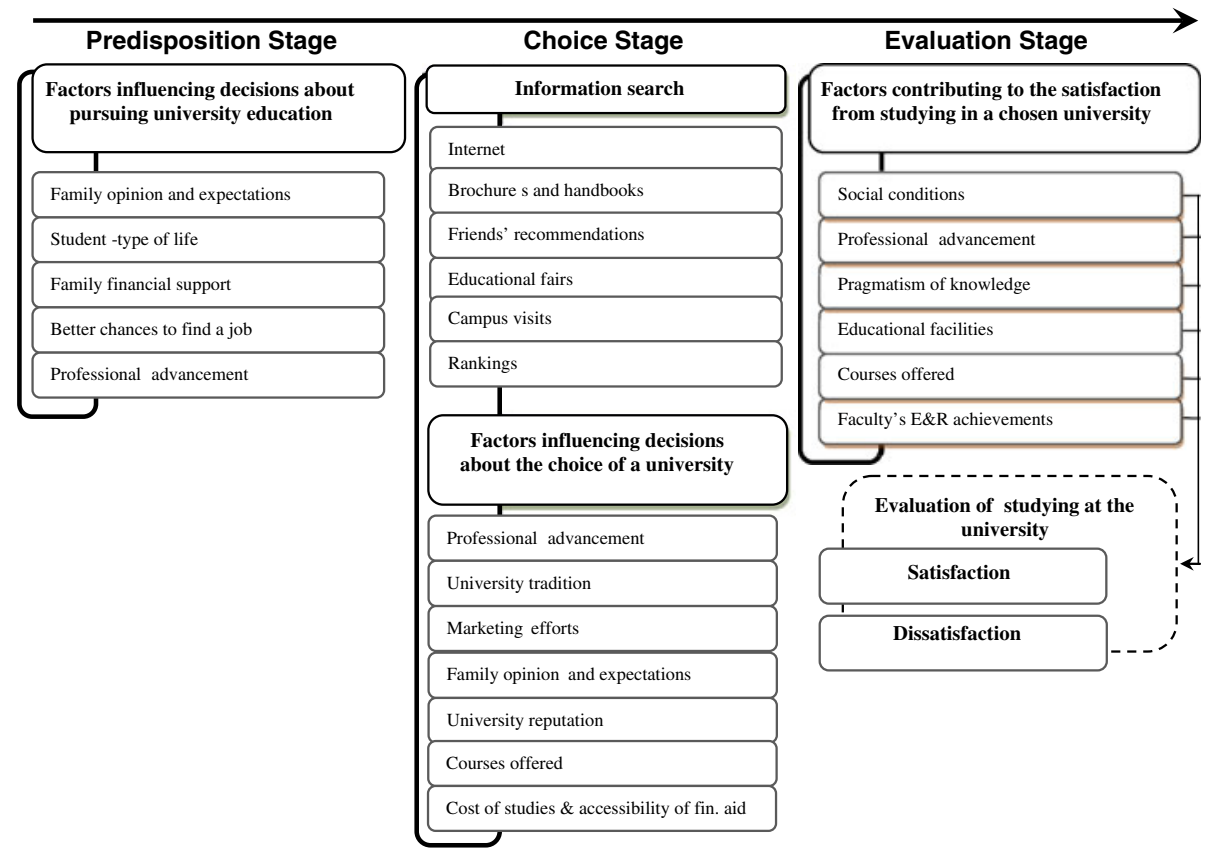

Fig. 2 Integrative Framework of University Choice Process in Poland

should focus on promoting clear links between their programs and the development of students' professional skills and personal talents.

Third, as family opinion and expectations were much more important in the predisposition stage than in the choice stage, it can be assumed that in Poland, family role is important in the decisions of a more generic nature. Parents help to decide the future of their children and often "play a role both as definers of career expectations and as role models" (García et al. 2007) which is evidenced by various researchers (Stage and Hossler 1989; Pimpa 2005; Sullivan 2006). Our research adds another important issue to the existing literature- while the generic decisions are made with important family contribution; the specific choices are made by an individual. Those choices are primarily based on the university potential to develop professional skills.

Fourth, our study, unlike other research findings (e.g. Aldemir and Gulcan 2004), showed that for Polish students the most important satisfaction determinant was "social conditions" (sports facilities, university canteen, coffee bars, parking spaces, subsidized accommodation). While social conditions were rarely mentioned in the choice stage, they primarily contribute to students' satisfaction. It may be a consequence of preferences expressed in the predisposition stage, which highlighted that one of the primary reasons for pursuing higher education was student-type of life.

Finally, it is worth notice that university tradition is the second most important factor in a university choice. The proliferation of universities in Poland after 1990 and the huge demand for university degrees had a negative consequences for educational quality (Ernst, Young Business Advisory and 2009). Many newly established business schools focused on earning money and were not interested in developing high quality programs. Although they gave an academic degree, employers quickly started to differentiate among the graduates of different schools. Later, many of those schools disappeared from the market, leaving 
graduated students unsure about the value of their academic diplomas. Therefore tradition and reputation started to play a growing role in the choice of a particular university, which also coincides with a similar observation made by Lang (2009).

Empirical findings of this research confirm that the choice of a university is a multidimensional process. It combines different choice factors at different stages of a decision making process, which further vary with respect to age, gender, and type of the university. Below we will discuss the influence of those control variables on students' choices.

First control variable that influenced students' responses was age. Older students with much more work experience, more often perceived a university degree as a way to find a new job or develop their skills, which is in line with other studies (Osborne et al. 2004). Citing the participants of focus groups, some mature students perceived that a university degree would help them: "to progress with my career", while others added "I am seeking a change in my life", or "It helps me to find my own identity".

Further analysis showed that students over 30 years old attributed higher importance to student-type of life and family opinion \& expectations. The difference within the first factor may come from students' need to distract themselves from the work and family responsibilities of various kinds, which was often mentioned in focus group discussions. The difference within the second factor can relate to the higher need of older students to consult decisions with their life partners. It can be also a result of generational changes. Young people (so called Y-generation) are much more exposed to the influence of globalized mental models than people above 30 . They are a much more socially conscious generation (being a part of many networks and using different social medias such as Facebook, Twitter, etc.), they use the internet to keep them aware of the possible choices, and they use multiple sources to search for information (Neuborne 1999; Twenge and Campbell 2008), which often decreases the role of family in their decisions.

Although female constitute $60 \%$ of all students of business studies in Poland (CSOP 2010a), they rely much more on social factors in their educational choices than male students. This study proved that female students more often considered family opinion and student-type of life in their decisions, while male students were more pragmatic and career oriented. Such results are in line with what we expected. Poland reports higher scores with regard to masculinity of its culture, which demonstrates higher polarization between the values of men and women in a society, with men being more oriented towards career and success, and women showing more social and family oriented values (Hofstede 2003). Various research show that women in Poland are much more affected by unemployment, are less paid for a similar job than men and occupy lower level of organizational hierarchies both in business and government institutions (CSOP 2007; Sroka 2008; Velkoff 1995). Adding to that the social perception of women "as secondary workers, often unable to commit themselves fully to their jobs and to pursue their careers because of their double role as workers and main providers of care for the household" (World Bank Report 2002, p. 9) may result in different role models and expectations from women and men in Poland.

Finally, this study highlights the differences among students who enrolled in public and non-public universities (as their primary choice). While choosing non-public universities students focus more on the professional advancement and university reputation. There are two reasons behind such results. First, this can be an expression of more attention given by students who have to pay for their studies (in Polish public universities full-time studies are free of charge). Those students may look more closely at potential earnings they may gain after graduating a university, which according to two-thirds of the focus group participants 
was professional advancement. Second, students of non-public universities are more sensitive to the reputation of their schools. This issue is particularly important in Poland, where as mentioned earlier the explosion of non-public universities that took place after 1990 , brought problems of quality of studies. Moreover the increasing unemployment among young university graduates (Polish Ministry of Education Report 2005), and a dramatic shift in population profiles (Beechler and Woodward 2009) along with a significant decline in the number of students, has increased the pressure for a good reputation that is perceived through a high quality of studies consistent with European standards.

\section{Implications and direction for future research}

In spite of the explosion of interest in education in Poland after 1990, only a handful of studies have researched Polish students' educational choices and the reasons behind those choices. We believe that such knowledge is valuable for a number of reasons. First, it can be helpful for foreign universities planning to enter the Polish educational market. Poland ranks as sixth of all 27 EU countries with regard to the size of its population and as such it has become attractive for foreign universities to open branches in Poland or to attract Polish students to their home facilities.

Second, the explosion of the educational sector in Poland throughout the 90s along with the present trend of declining numbers of students have substantially increased competition and made universities particularly alert about marketing effectiveness and students' satisfaction. Therefore the knowledge about how students chose a university and which factors influence their satisfaction may not only help to target marketing efforts more effectively, but can also help to decrease the withdrawal level. It can also help in improved planning and more informed policy making on the part of tertiary education management.

This study has several limitations, there is a probability that other significant choice factors exists, which our study did not cover. As more research is needed, our exploratory study can however be considered a good starting point for further investigations. Particularly, further research is needed to identify to what degree the level of satisfaction influences continuing education at the initial institution. In addition, since our study is limited to students of business majors, there is a need for further comparative studies to find out if those results can be generalisable to other fields of studies.

Despite above limitations, this study contributes significantly to the knowledge about the higher education choices on the different levels of the decision making process. It shows that the decision making is multifaceted and longitudinal as it combines the different choice factors at different stages of a decision making process and further vary with respect to individual characteristics.

Open Access This article is distributed under the terms of the Creative Commons Attribution Noncommercial License which permits any noncommercial use, distribution, and reproduction in any medium, provided the original author(s) and source are credited.

\section{Appendix}

See Table 9. 
Table 9 Variables which loaded on the factors

Original variables (scale $1-5$ )

While making a decision about pursuing higher education how important for you was

Student-type of life

Professional advancement

Family opinion and expectation

Family financial support

Better chances to find a job

Professional advancement

University tradition

Courses offered

University reputation

Family opinion and expectations

Marketing efforts

To move out from family house

To join students' organizations

To socialize with other students

Varied and interesting social life

To develop professional skills

Intellectual and personal development

Opportunity to gain experience in foreign universities through exchange programs

To develop foreign language skills

Continuity of family tradition

To meet demands of your parents

Family opinion

Financial aid from your parents

Financial status of your parents

The chance to enhance your career prospects

A desire to find a better job in Poland or abroad

To invest in your skills to have a better position

While making a university choice how important for you was

Marketing information obtained from the university

University website

Recruitment information and the speed of application process

The quality of communication with first-contact university personnel

Better chances to develop professional skills

Intellectual and personal development

Opportunity to gain experience in foreign universities through exchange programs

Opportunity to develop foreign language skills

The tradition of the university

The year when the university was founded

Number of well-known/successful alumni of the university

Practical usefulness of courses offered

Availability of challenging courses

The quality of the courses/program

A wider course offering

To receive a diploma from well-known university

The reputation of the university

The ranking of the university

The ranking of the program

Your family opinion

Recommendations from your parents/spouse/partner

Your family members/colleagues have studied at this university 
Table 9 continued

Original variables (scale 1-5)

Cost of studies and accessibility of financial aid
Cost of studies

Availability of financial aid

Ability to work part time

To what degree the following variables influence your satisfaction from studying at the present university

Professional advancement

Pragmatism of knowledge

Courses offered

Educational facilities

Social conditions
Better chances to develop professional skills

Opportunity of intellectual and personal development

Opportunity to gain experience in foreign universities through exchange programs

Opportunity to develop foreign language skills

Possibilities of using acquired knowledge and skills in practice

Acquiring knowledge that will give you professional independence

Opinion about university's graduates among employers

Practical usefulness of courses offered

Availability of challenging courses

The quality of the courses/program

A wide course offering

Small class sizes

Access to professional and educational databases

Classroom equipment

University-wide access to internet, computers and audiovisual aids

Good sport facilities

University canteen and coffee bars

Parking spaces

Subsidized accommodation

Application of newest teaching methods

High level of interaction among professors and students

Research ranking of the university

The reputation of faculty members

High professional qualifications of faculty

Research achievements of professors

\section{References}

Aitken, N. D. (1982). College student performance, satisfaction, and retention. Journal of Higher Education, 53,32 .

Aldemir, C., \& Gulcan, Y. (2004). Students satisfaction in higher education: A Turkish case. Higher Education Management and Policy, 16(2), 109-122.

Bean, J. P., \& Bradley, R. K. (1986). Untangling the satisfaction-performance relationship for college students. Journal of Higher Education, 57(4), 393.

Beechler, S., \& Woodward, I. C. (2009). The global 'war for talent'. Journal of International Management. doi:10.1016j.intman.2009.01.002.

Brinkworth, R., McCann, B., Matthews, C., \& Nordström, K. (2009). First year expectations and experiences: Student and teacher perspectives. Higher Education, 58(2), 157-173. 
Cabrera, A. F., Vries, W., \& Anderson, S. (2008). Job satisfaction among Mexican alumni: A case of incongruence between hunch-based policies and labor market demands. Higher Education, 56, 699-722.

Central Statistical Office of Poland. (CSOP). (2007). Women in Poland. Warsaw: Statistical Publishing Establishment.

Central Statistical Office of Poland. (CSOP). (2009). Demographic yearbook of Poland. Warsaw: Statistical Publishing Establishment.

Central Statistical Office of Poland. (CSOP). (2010a). Higher education institutions and their finances in 2009. Warsaw: Statistical Publishing Establishment.

Central Statistical Office of Poland (CSOP). (2010b). Statistical yearbook of the Republic of Poland. Warsaw: Statistical Publishing Establishment.

Chapman, R. G. (1986). Toward a theory of college selection: A model of college search and choice behavior. Advances in Consumer Research, 13, 246-250.

Chen, L. H. (2007). Choosing Canadian graduate schools from afar: East Asian students' perspectives. Higher Education, 54, 759-780.

Cremonini, L., Westerheijden, D., \& Enders, J. (2008). Disseminating the right information to the right audience-cultural determinants in the use (and misuse) of rankings. Higher Education, 56(2), 373-385.

Ernst \& Young Business Advisory and Instytut Badań nad Gospodarką Rynkową. (2009). Diagnoza stanu szkolnictwa wyższego w Polsce. Warsaw: Instytut Badań nad Gospodarką Rynkową.

García, A., Gabaldón, D., Mora, J. G., \& Vila, L. E. (2007). The relationship between life goals and fields of study among young European graduates. Higher Education, 53(6), 843-865.

Gazeta Prawna. (2011). Studia: rekrutacja na kierunki zamawiane poza kontrolą, March 9.

Hanson, K., \& Litten, L. (1982). Mapping the road to academia: A review of research on women, men, and the college selection process. In P. Perun (Ed.), The undergraduate woman: Issues in education. Lexington, MA: Lexington.

Hofstede, G. (2003). Culture's consequences, comparing values, behaviors, Institutions and Organizations Across Nations. Thousand Oaks, California: Sage Publications.

Hossler, D., \& Gallagher, K. S. (1987). Studying student college choice: A three-phase model and implications for policy makers. College and University, 2, 207-221.

Hossler, D., Schmit, J., \& Vesper, N. (1999). Going to college: How social, economic, and educational factors influence the decisions students make. Baltimore: Johns Hopkins University Press.

Jackson, G. A. (1982). Public efficiency and non-public choice in higher education. Educational Evaluation and Policy Analysis, 4(2), 237-247.

Jimenez, J., \& Salas-Velasco, M. (2000). Modeling educational choices. A binomial logit model applied to the demand for higher education. Higher Education, 40, 293-311.

Kohn, M., Manski, C., \& Mundel, D. (1976). An empirical investigation of factors which influence college going behavior. Annals of Economic and Social Measurement, 5, 391-419.

Koivula, J., \& Rinne, R. (2006). The dilemmas of the changing university. Turku: European Universities for Entrepreneurship.

Kula, M. (2008). 'Niż zdziesiątkuje prywatne uczelnie w całej Polsce', Polska. The Times. August 12.

Kwiek, M. (2003). Academe in transition: Transformations in the Polish academic profession. Higher Education, 45, 455-476.

Lang, D. W. (2009). Articulation, transfer, and student choice in a binary post-secondary system. Higher Education, 57(3), 355-371.

Lee, G., Jolly, N., Kench, P., \& Gelonesi, B. (2000). 'Factors related to student satisfaction with university. In Presented at the 4th Pacific Rim-first year in higher education conference: Creating futures for a new millennium, Brisbane.

Lloyd, T. (Ed.). (2005). College unranked: Ending the college admission frenzy. Cambridge: Harvard University Press.

Menon, M. (2004). Information search as an indication of rationality in student choice of higher education. Higher Education, 12(3), 267-283.

Menon, M. E., Saiti, A., \& Socratous, M. (2007). Rationality, information search and choice in higher education: Evidence from Greece. Higher Education, 54, 705-721.

Mintzberg, H., Raisinghani, D., \& Theoret, A. (1976). The structure of "unstructured" decision processes. Administrative Science Quarterly, 21, 246-275.

Montmarquette, C., Cannings, K., \& Mahseredjian, S. (2002). How do young people choose college majors? Economics of Education Review, 21, 543-556.

Neuborne, E. (1999-02-15). Generation Y. Today's teens the biggest bulge since the boomers may force marketers to toss their old tricks. Business Week Online, retrieved September 10, 2010, http://www.businessweek.com/1999/99_07/b3616001.htm. 
Nunnally, J. C. (1978). Psychometric theory (2nd ed.). New York: McGraw-Hill.

OECD. (2009). Education at a glance 2009: OECD indicators. Paris: OECD.

Osborne, M., Marks, A., \& Turner, E. (2004). Becoming a mature student: How adult applicants weigh the advantages and disadvantages of higher education. Higher Education, 48, 291-315.

Pike, G. R. (1991). The effects of background, coursework, and involvement on students' grades and satisfaction. Research in Higher Education, 32(1), 15.

Pimpa, N. (2005). A family affair: The effect of family on Thai students' choices of international education. Higher Education, 49, 43-48.

Polish Ministry of Education Report. (2005). "Wyksztatcenie i kompetencje”. Narodowy Plan Rozwoju 2007-2013. Warsaw: Polish Ministry of Education.

Rausch, J. L., \& Hamilton, M. W. (2006). Goals and distractions: Explanations of early attrition from traditional university freshmen. The Qualitative Report, 11(2), 317-334.

Rochat, D., \& Demeulemeester, J. L. (2001). Rational choice under unequal constraints: The example of Belgian higher education. Economics of Education Review, 20, 15-26.

Rozanski, A. (2008). The educational orientation of participants in postgraduate managerial study programs in Poland. Human Resource Development International, 11(1), 91-99.

Soja, P. (2008). Difficulties in enterprise system implementation in emerging economies: Insights from an exploratory study in Poland. Information Technology for Development, 14(1), 31-51.

Somers, P., Cofer, J,. \& Putten, J. V. (1999). The influence of early aspirations and attitudes on postsecondary attendance. In Presented at American Educational Research Association Conference, Montreal, Canada.

Sroka, J. (2008). Economic activity and earnings of women. Warsaw: Institute of Public Affairs.

Stage, F. K., \& Hossler, D. (1989). Differences in family influences on college attendance plans for male and female ninth graders. Research in Higher Education, 30(3), 301-315.

Sullivan, A. (2006). Students as rational decision-makers: The question of beliefs and attitudes. London Review of Education, 4(3), 271-290.

Taylor, J. S., Brites, R., Correia, F., Farhangmehr, M., Ferreira, B., Machado, M. L., et al. (2008). Strategic enrolment management: Improving student satisfaction and success in Portugal. Higer Education Management and Policy, 20(1), 129-145.

Tinto, V. (1993). Leaving college: Rethinking the causes and cures of student attrition. Chicago: University of Chicago Press.

Twenge, J. M., \& Campbell, S. M. (2008). Generational differences in psychological traits and their impact on the workplace. Journal of Managerial Psychology, 23(8), 862-877.

UN Report. (2005). World population prospects. The 2004 revision. New York: United Nations.

Usher, A. (2009). Ten years back and ten years forward: Developments and trends in higher education in Europe region, UNESCO forum on higher education in the Europe Region: Access, values, quality and competitiveness, 21-24 May. Romania: Bucharest.

Velkoff, V. A. (1995). Women in Poland. US: US International Programs Center.

Wedley, W. C., \& Field, R. H. G. (1984). A predecision support system. Academy of Management Review, 9, 696-703.

World Bank Report. (2002). Gender in transition. Human Development Unit, Eastern Europe and Central Asia Region: Washington DC. May 21. 